\title{
Coupling of narrow and wide band-gap semiconductors on uniform films active in bacterial disinfection under low intensity visible light: Implications of the interfacial charge transfer (IFCT)
}

\author{
S. Rtimi ${ }^{\mathrm{a}, \mathrm{b}, *}$, R. Sanjines $^{\mathrm{c}}$, C. Pulgarin ${ }^{\mathrm{a}, * *}$, A. Houas $^{\mathrm{b}}$, J.-C. Lavanchy $^{\mathrm{d}}$, J. Kiwi ${ }^{\mathrm{e}}$ \\ a Ecole Polytechnique Fédérale de Lausanne, EPFL-SB-ISIC-GPAO, Station 6, CH-1015 Lausanne, Switzerland \\ ${ }^{\mathrm{b}}$ UR Catalyse/Matériaux pour l'Environnement et les Procédés (URCMEP), Faculté des Sciences de Gabès, Université de Gabès, 6072 Gabès, Tunisia \\ ${ }^{\mathrm{C}}$ Ecole Polytechnique Fédérale de Lausanne, EPFL-SB-IPMC-LNNME, Bat PH, Station 3, CH1015 Lausanne, Switzerland \\ ' Université de Lausanne, IMG, Centre d'Analyse Minérale, Bat Anthropole, CH-1015 Lausanne, Switzerland \\ e Ecole Polytechnique Fédérale de Lausanne, EPFL-SB-ISIC-LPI, Bat Chimie, Station 6, CH1015 Lausanne, Switzerland
}

\section{H I G H L I G H T S}

- Design, preparation, testing and characterization of uniform sputtered films.

- Interfacial charge transfer from the $\mathrm{Ag}_{2} \mathrm{O}(\mathrm{cb})$ to the lower laying $\mathrm{Ta}_{2} \mathrm{O}_{5}(\mathrm{cb})$.

- The optical absorption of TaON and TaON/Ag was proportional to E. coli inactivation.

- Self-cleaning of the TaON/Ag polyester enables repetitive $E$. coli inactivation.

\section{A R T I C L E I N F O}

\section{Article history:}

Received 14 January 2013

Received in revised form 7 June 2013

Accepted 9 June 2013

Available online 15 June 2013

\section{Keywords:}

$\mathrm{TaON} / \mathrm{Ag}$

Sputtering/co-sputtering

E. coli inactivation

Visible light

\begin{abstract}
A B S T R A C T
This study reports the design, preparation, testing and surface characterization of uniform films deposited by sputtering $\mathrm{Ag}$ and $\mathrm{Ta}$ on non-heat resistant polyester to evaluate the Escherichia coli inactivation by TaON, TaN/Ag, $\mathrm{Ag}$ and TaON/Ag polyester. Co-sputtering for $120 \mathrm{~s}$ Ta and $\mathrm{Ag}$ in the presence of $\mathrm{N}_{2}$ and $\mathrm{O}_{2}$ led to the faster $E$. coli inactivation by a TaON/Ag sample within $\sim 40$ min under visible light irradiation. The deconvolution of TaON/Ag peaks obtained by X-ray photoelectron spectroscopy (XPS) allowed the assignment of the $\mathrm{Ta}_{2} \mathrm{O}_{5}$ and $\mathrm{Ag}$-species. The shifts observed for the XPS peaks have been assigned to $\mathrm{AgO}$ to $\mathrm{Ag}_{2} \mathrm{O}$ and $\mathrm{Ag}^{0}$, and are a function of the applied sputtering times. The mechanism of interfacial charge transfer (IFCT) from the $\mathrm{Ag}_{2} \mathrm{O}$ conduction band (cb) to the lower laying $\mathrm{Ta}_{2} \mathrm{O}_{5}(\mathrm{cb}$ ) is discussed suggesting a reaction mechanism. The optical absorption of the TaON and TaON/Ag samples found by diffuse reflectance spectroscopy (DRS) correlated well with the kinetics of $E$. coli inactivation. The TaON/Ag sample microstructure was characterized by contact angle (CA) and by atomic force microscopy (AFM). Self-cleaning of the TaON/Ag polyester after each disinfection cycle enabled repetitive $E$. coli inactivation.
\end{abstract}

(C) 2013 Elsevier B.V. All rights reserved.

\section{Introduction}

Antimicrobial surfaces reduce or eliminate hospital-acquired infections (HAI) due to antibiotic resistant bacteria that survive nowadays on hospital surfaces for long times [1]. More effective antibacterial films are needed at present due to the increasing resistance of pathogenic bacteria to synthetic antibiotics when administered for long times [2]. Recently, Mills et al. [3], Parkin

\footnotetext{
* Corresponding author at: Ecole Polytechnique Fédérale de Lausanne, EPFL-SBISIC-GPAO, Station 6, CH-1015 Lausanne, Switzerland. Tel.: +41216936150.

** Corresponding author. Tel.: 041216934720.

E-mail addresses: sami.rtimi@epfl.ch (S. Rtimi), cesar.pulgarin@epfl.ch (C. Pulgarin).
}

et al. [4-7], Foster et al. [8], Dunlop et al. [9] and Yates et al. [10] have reported antibacterial films of $\mathrm{Ag}$ and $\mathrm{Cu}$ films on glass and thin polymer films by chemical vapor deposition (CVD) and in some cases sputtering techniques.

Most of the semiconductors have too large band-gaps to absorb visible light. This is because their band-gap consists mainly of $\mathrm{O} 2 \mathrm{p}$ orbitals with energies of about $\mathrm{ca} .3 \mathrm{eV}$. Recently studies have shown that the optical absorption of $\mathrm{TiO}_{2}$ can be shifted toward the visible range by introducing mid-gap levels above the top of the $\mathrm{O} 2 \mathrm{p}$ valence band by addition of nitrogen [11]. This study presents details of the coupling of a small bang-gap semiconductor $\mathrm{Ag}_{2} \mathrm{O}$ (bg $\sim 1.5 \mathrm{eV}$ ) absorbing visible light being coupled with a large band semiconductor $\mathrm{Ta}_{2} \mathrm{O}_{5}(\mathrm{bg} \sim 4.0 \mathrm{eV})$.

The sputtering of oxides/nitrides allows the preparation of adhesive films, which are mechanically stable and superior to films 
prepared by deposition of colloid/powders, which can be readily wiped off using a cloth or thumb [12]. Our laboratory has recently reported oxy-nitrides films [13] and nitrides [14] films inactivating bacteria under visible light irradiation. $\mathrm{Ag}$ has been reported not to be miscible with TaN in nanocomposite films $[15,16]$. When using Ag-loaded textiles, silver leaching takes place and is an undesired environmental problem. Textiles with an improved Ag-adhesion are needed at the present time [17].

In this study we present: (a) the sputtering of $\mathrm{Ag}$, Ta in reactive $\mathrm{N}_{2} / \mathrm{O}_{2}$ atmosphere and co-sputtering of Ta/Ag also in the presence of $\mathrm{N}_{2}$ and $\mathrm{O}_{2}$ on polyester, (b) the evaluation of the Escherichia coli inactivation kinetics on nitride and oxy-nitride films and of uniform films of Ag-nitride and Ag-oxynitride, (c) a mechanism for the photo-induced electron injection from the conduction band $(\mathrm{cb})$ of $\mathrm{Ag}_{2} \mathrm{O}$ into the conduction band (cb) of $\mathrm{Ta}_{2} \mathrm{O}_{5}$ for the TaON/Ag sample and (d) the surface characterization of the antibacterial films by up-to-date techniques.

\section{Experimental}

\subsection{Direct current $(D C)$ and $D C$-pulsed $(D C P)$ magnetron sputtering}

Direct current (DC) magnetron sputtering of metals and semiconductor oxides on diverse substrates has been recently reported by our laboratory $[13,14]$. Fig. 1 shows the magnetron chamber used, being the substrate-to-target distance $\sim 10 \mathrm{~cm}$. The Ta-target was two inches diameter (Lesker Hastings, East Sussex, UK). The amount of $\mathrm{O}_{2}$ changes in the gas composition changes the appearance of the TaON films in the magnetron chamber. A reactive gas mixture $5 \% \mathrm{~N}_{2} / 5 \% \mathrm{O}_{2} / 90 \%$ Ar was used in the sputtering chamber to deposit the TaON layers on the polyester and the total pressure was set at $0.1 \mathrm{~Pa}$. The DC-sputtering was carried applying $280 \mathrm{~mA}$ and a negative bias of $-330 \mathrm{~V}$ ( $90 \mathrm{~W}$, current density of $12.7 \mathrm{~mA} / \mathrm{cm}^{2}$ ). The polyester samples were $2 \mathrm{~cm} \times 2 \mathrm{~cm}$ in size.

Direct current pulsed magnetron sputtering (DCP) was used to sputter Ag on the polyester (see Fig. 1a). The Ag-target was two inches in diameter (Lesker, Hastings, East Sussex, UK). A negative voltage of $-500 \mathrm{~V}$ was applied and then switched to $+75 \mathrm{~V}(15 \%$ of $-500 \mathrm{~V})$. The DCP-pulses of $10 \mu \mathrm{s}$ were applied with $280 \mathrm{~mA}$, ( $198 \mathrm{~W}, 40 \mathrm{~W} /$ pulse). The calibration of films thickness for the TaON and for Ag-layers was carried out on Si-wafers with a profilometer (Alphastep500, TENCOR) and the results shown in Fig. 1b. TENCOR. The experimental values were in an error of $\pm 10 \%$.

The polyester was an EMPA test cloth sample No. 407. It is a polyester Dacron polyethylene-terephthalate; type 54 spun, plain weave ISO 105-F04 used for color fastness determinations. The thermal stability of Dacron polyethylene terephthalate has been reported as $140^{\circ} \mathrm{C}$ for times $\leq 1 \mathrm{~min}$. The thickness of the polyester was $130 \mu \mathrm{m}$.

\subsection{X-ray fluorescence (XRF) of the Ta/Ag-content in sputtered samples}

The Ag- and Ta-content of the polyester was evaluated by Xray fluorescence in a PANalyticalPW2400 spectrometer. Using this technique, each element emits an X-ray of a certain wavelength associated with its particular atomic number.

\subsection{Diffuse reflectance spectroscopy (DRS) and irradiation procedures}

Diffuse reflectance spectroscopy was carried out using a Perkin Elmer Lambda 900 UV-vis-NIR spectrometer provided for with a PELA-1000 accessory within the wavelength range of $200-800 \mathrm{~nm}$
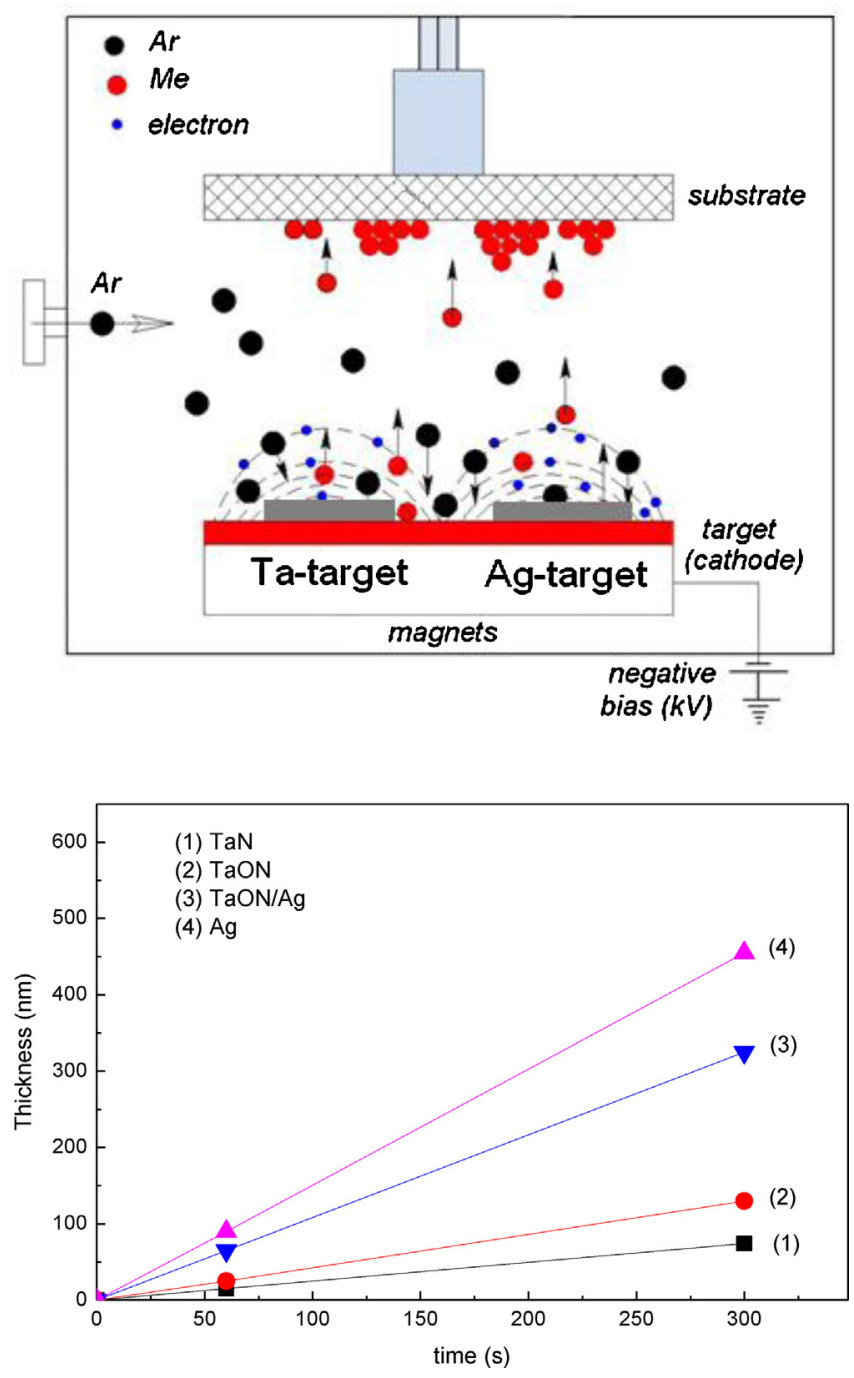

Fig. 1. (a) Schematic of the two-target direct current magnetron-sputtering chamber and (b) thickness calibration of TaN, TaON, TaON/Ag and Ag layers on Si-wafers as a function of sputtering time.

and a resolution of $1.0 \mathrm{~nm}$. The absorption of the samples was plotted in Kubelka-Munk (KM) arbitrary unit vs wavelength.

Irradiation of the sputtered polyester samples was carried out in a tubular cavity by Osram Lumilux $18 \mathrm{~W} / 827$ actinic lamps. The light emitted was in the visible region (340-700 nm). Each lamp has an integral output of $1.2 \mathrm{~mW} / \mathrm{cm}^{2}$ and resembled the solar spectrum. These actinic lamps are used generally in hospitals and provide an efficient compromise of energy consumption per irradiated lumen. The bacterial inactivation kinetics was determined also as a function of the applied light intensity.

\subsection{E. coli inactivation evaluation}

The samples of $E$. coli K12 was obtained from the Deutsche Sammlung von Mikroorganismen und Zellkulturen GmbH (DSMZ) ATCC23716, Braunschweig, Germany to test the antibacterial activity of the sputtered polyester fabrics. The polyester fabrics were sterilized by autoclaving at $121^{\circ} \mathrm{C}$ for $2 \mathrm{~h}$. $20 \mu \mathrm{L}$ aliquot of culture with an initial concentration of $1.4 \times 10^{6} \mathrm{CFU} \mathrm{mL}^{-1}$ in $\mathrm{NaCl} / \mathrm{KCl}$ was placed on each coated and uncoated (control) polyester fabric. The samples were placed on Petri dish provided with a lid to prevent evaporation. After each determination, the fabric was transferred into a sterile $2 \mathrm{~mL}$ Eppendorf tube containing $1 \mathrm{~mL}$ autoclaved 
$\mathrm{NaCl} / \mathrm{KCl}$ saline solution. This solution was subsequently mixed thoroughly using a Vortex for $3 \mathrm{~min}$. Serial dilutions were made in $\mathrm{NaCl} / \mathrm{KCl}$ solution. A $100-\mu \mathrm{L}$ sample of each dilution was pipetted onto a nutrient agar plate and then spread over the surface of the plate using standard plate method. Agar plates were incubated lid down, at $37^{\circ} \mathrm{C}$ for $24 \mathrm{~h}$ before colonies were counted. The bacterial data reported were replicated three times. To verify that no re-growth of $E$. coli occurs after the total inactivation observed in the first disinfection cycle, the TaON and TaON-Ag samples were incubated for $24 \mathrm{~h}$ at $37^{\circ} \mathrm{C}$. Then bacterial suspension of $100 \mu \mathrm{L}$ was deposited on 3 Petri dishes to obtain replicates of the bacterial counting. These samples are incubated at $37^{\circ} \mathrm{C}$ for $24 \mathrm{~h}$. No bacterial re-growth was observed. The statistical analysis of the results was performed for the decrease of the CFU values calculating the standard deviation values. The average values were compared by one-way analysis of variance and with the value of statistical significance.

\subsection{Contact angle (CA) and atomic force microscopy (AFM)}

The contact angles to determine the hydrophobicity of the polyester samples were assessed by means of a DataPhysics OCA 35 unit following the sessile drop.

Atomic force microscopy (AFM) of sputtered samples was performed with a Parks Scientific XE120 AFM in contact mode. The Cantilever used was an Olympus OMCL-TR400 with a spring constant $0.02 \mathrm{~N} / \mathrm{m}$. Images with a scanning field $600 \mathrm{~nm} \times 300 \mathrm{~nm}$ were taken using a line frequency $2 \mathrm{~Hz}$. The roughness was calculated using Parks' XEI software.

\subsection{X-ray photoelectron spectroscopy (XPS)}

An AXIS NOVA photoelectron spectrometer (Kratos Analytical, Manchester, UK) equipped with monochromatic Al $\mathrm{K} \alpha$ $(h v=1486.6 \mathrm{eV})$ anode was used during the study. The electrostatic charge effects on the samples were compensated by means of the low-energy electron source working in combination with a magnetic immersion lens. The carbon $\mathrm{C} 1 \mathrm{~s}$ line with position at $284.6 \mathrm{eV}$ was used as a reference to correct for Ag-charging effects. The quantitative surface atomic concentration of some elements was determined from peak areas using known sensitivity factors [18]. Charging effects were corrected according to Shirley [19]. Casa XPS-Vision 2 software attached to the Kratos Analytical unit deconvoluted XPS spectra.

\subsection{Transmission electron microscopy (TEM)}

A Philips CM-12 (field emission gun, $300 \mathrm{kV}, 0.17 \mathrm{~nm}$ resolution) microscope at $120 \mathrm{kV}$ was used to measure grain size of the Agfilms. The textiles were embedded in epoxy resin 45359 Fluka and the fabrics were cross-sectioned with an ultramicrotome (Ultracut E) and at a knife angle at $35^{\circ}$. Images were taken in Bright Field (BF) mode for the samples sputtered by DC and DCP.

\section{Results and discussion}

\subsection{Film thickness and profilometry}

Fig. 1b shows the results for the thickness calibration of sputtered TaN, TaON, Ag and co-sputtered TaON/Ag layers on the polyester. The fastest bacterial inactivation kinetics was observed for co-sputtered TaON/Ag layers for 2 min of $\sim 130 \mathrm{~nm}$ thick. This is equivalent to 650 layers. Assuming each layer with $10^{15}$ atoms $/ \mathrm{cm}^{2}$ a deposition rate of $\sim 5.4 \times 10^{15}$ atoms $/ \mathrm{cm}^{2} \mathrm{~s}$ can be estimated [20]. Recent work in our laboratory showed a faster bacterial inactivation of $E$. coli on Ag-films sputtered by DCP compared to DC-sputtered Ag-films [21].

\subsection{E. coli inactivation on TaN/Ag and TaON/Ag films: effect of the light dose and bacterial concentration}

The bacterial inactivation becomes faster for increasing TaNsputtering times. Fig. 2a shows that sputtering TaN for $120 \mathrm{~s}$ inactivated bacteria within $300 \mathrm{~min}$. Fig. 2a, trace 5) shows that in the dark no bacterial inactivation on TaN/Ag-polyester. TaN/Ag shows a faster bacterial inactivation compared to TaN films and inactivate $E$. coli within $120 \mathrm{~min}$ for a 120 s co-sputtered sample. Fig. 2a, traces 3 shows bacterial inactivation for TaN/Ag surfaces co-sputtered for $60 \mathrm{~s}$. Since the $E$. coli inactivation time for samples sputtered for $120 \mathrm{~s}$ becomes shorter, a $60 \mathrm{~s}$ sputtering time did not deposit sufficient TaN/Ag layers or did not allow a full light absorption of the incident visible light. A sample of TaN/Ag co-sputtered for 120 shows an inactivation time of $120 \mathrm{~min}$. The cosputtered TaN/Ag (150 s) sample (Fig. 2a, trace 2 ) is seen to inactivate E. coli at longer times compared to the TaN/Ag co-sputtered sample for $120 \mathrm{~s}$ (Fig. 2a, trace 1). This is due probably to: (a) bigger Ag-clusters hindering the diffusion of charges between TaN and the Ag layers, (b) a decrease in the number of surface catalytic sites available for bacterial inactivation [13,14], and (c) an excess of $\mathrm{Ag}$ acting as recombination centers for the photo-induced charges on the sample surface.

Fig. 2b shows the bacterial inactivation kinetics on $\mathrm{TaON} / \mathrm{Ag}$ polyester under $\mathrm{O}_{2} / \mathrm{N}_{2} / \mathrm{Ar}$ atmosphere. A $6 \log _{10}$ (99.99\%) reduction in the bacterial concentration was observed within $\sim 40$ min for the $\mathrm{TaON} / \mathrm{Ag}$ co-sputtered sample for $120 \mathrm{~s}$. Sequential sputtering of Ta and $\mathrm{Ag}$ lead to a slower bacterial inactivation than the co-sputtered samples as shown in Fig. 2b, trace 4. A darker gray metallic Agcolor was observed on the polyester sputtered with Ta followed by Ag. This sample was not investigated further. The Ag-sputtering on TaON leads to bigger size Ag-agglomerates hindering the efficient transfer of charges as well as light penetration into the sample [21].

The shorter bacterial inactivation kinetics reported in Fig. 2b compared to Fig. 2a can be rationalized considering that reactive sputtering in the presence of $\mathrm{O}_{2}$ introduces in the TaN ionic metal-oxygen species in a matrix of covalent metal-nitrogen bonds [22]. The polarity introduced by these metal-oxygen species is due to the Van der Waals forces comprising: permanent dipoles, induced dipoles and hydrogen bonds. The surface energy of the TaON-Ag surfaces (Fig. 2b) is higher than the one available on the $\mathrm{TaN} / \mathrm{Ag}$ (Fig. 2a) surface due to the presence of ionic Ag-O metal oxygen species. Fig. 2c shows that Ag sputtered on polyester does not lead to complete bacterial inactivation even after $6 \mathrm{~h}$ of irradiation. Fig. $2 \mathrm{~d}$ shows that TaON samples sputtered on polyester for $120 \mathrm{~s}$ inactivated bacteria within $90 \mathrm{~min}$. This is two times longer than the time required by $\mathrm{TaON} / \mathrm{Ag}$ due to an interfacial charge transfer between $\mathrm{Ag}$ and $\mathrm{TaON}$ and this point will be discussed taking into account the optical absorption of the sample as determined by DRS spectroscopy. Fig. 2e shows the $E$. coli inactivation time as a function of the $\mathrm{TaON} / \mathrm{Ag}$ layer thickness showing that a $130 \mathrm{~nm}$ coating leads to the shortest bacterial inactivation. For very thin TaON/Ag thicknesses below $50 \mathrm{~nm}$, the microstructure of the film seems not to be effective in inducing fast bacterial inactivation kinetics. This is confirmed in Fig. 2e for coatings of $20 \mathrm{~nm}$.

Fig. 3a presents the bacterial inactivation kinetics on $\mathrm{TaON} / \mathrm{Ag}$ co-sputtered samples for $120 \mathrm{~s}$ under three different light doses from a Lumilux Osram 18 W/827 lamp. Fig. 3b shows the bacterial inactivation kinetics of $E$. coli on $\mathrm{TaON} / \mathrm{Ag}$ co-sputtered samples $120 \mathrm{~s}$ under a Lumilux Osram $18 \mathrm{~W} / 827$ light for three bacterial initial concentrations. As expected the higher bacterial 

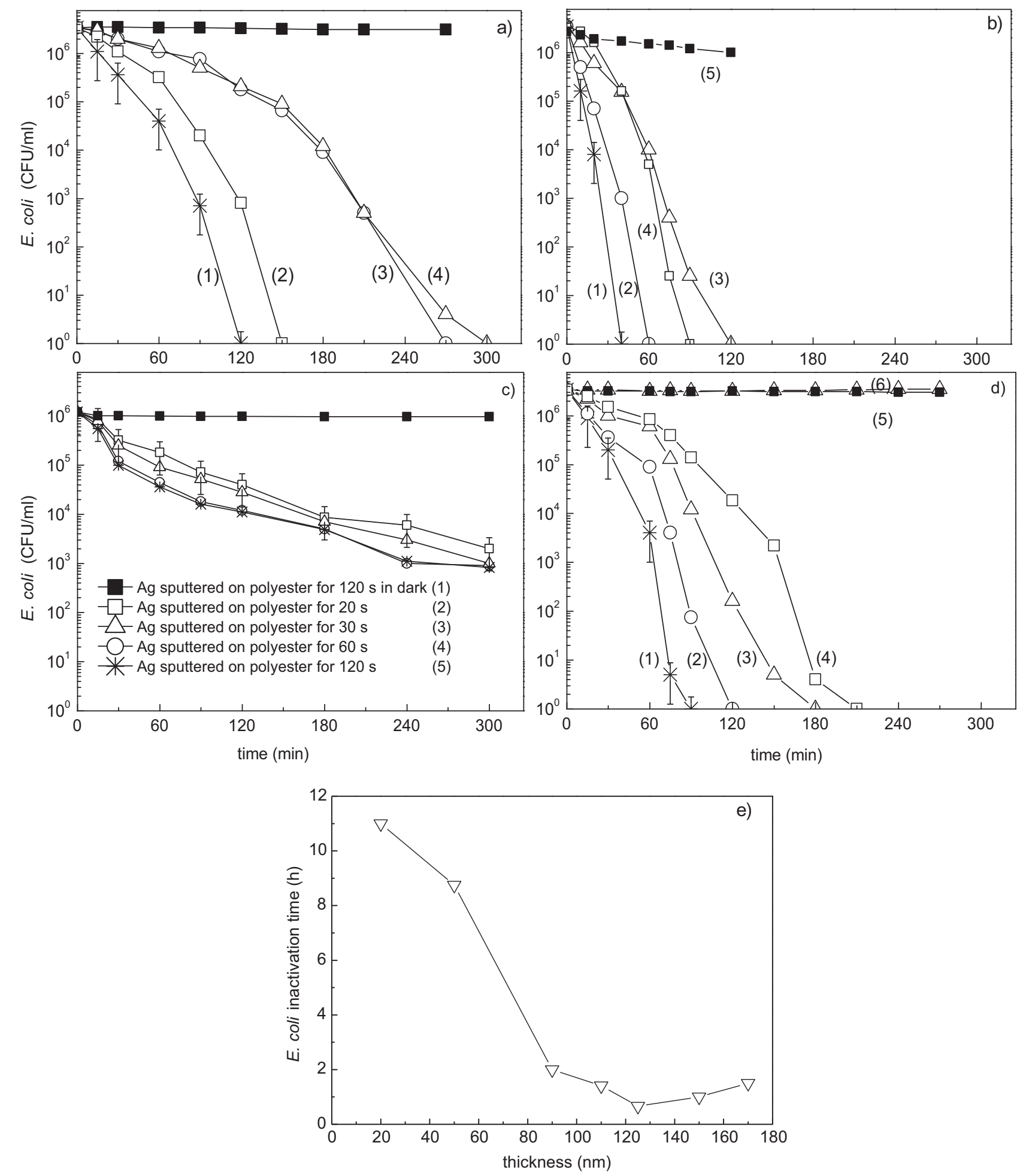

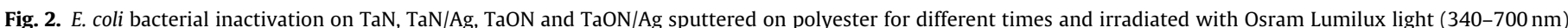

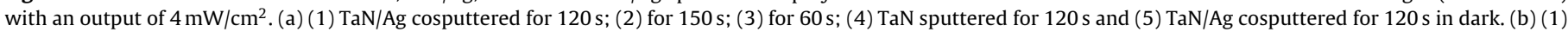

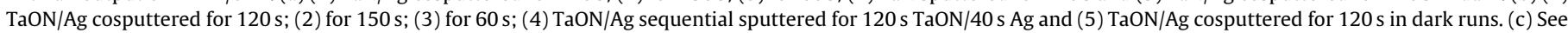

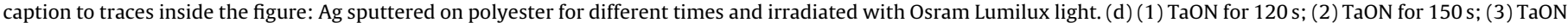

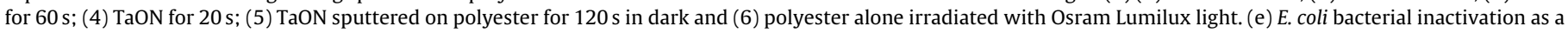
function of the thickness of TaON/Ag film on polyester and irradiated with Osram Lumilux 18 W827 actinic light.

concentration needed longer inactivation time. This observation makes it possible to exclude a strong absorption of E. coli on the TaON/Ag surfaces decreasing the light absorption on the film surface.

\subsection{DRS of the TaON and Co-sputtered TaON/Ag samples}

Fig. 4a shows the diffuse reflectance spectra of sputtered TaON. A significant shift in the absorption onset of TaON was observed 

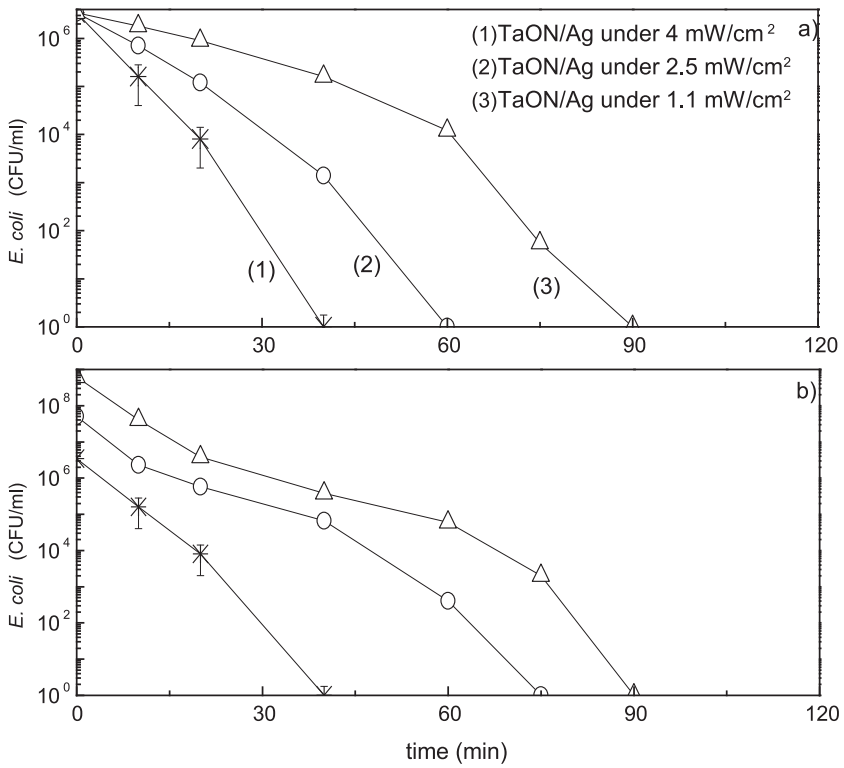

Fig. 3. E. coli bacterial inactivation kinetics on $\mathrm{TaON} / \mathrm{Ag}$ co-sputtered on polyester: (a) effect of light dose on $E$. coli inactivation kinetics using an Osram Lumilux light (340-700 nm) and (b) effect of initial concentration of bacteria under the same light with an output of $4 \mathrm{~mW} / \mathrm{cm}^{2}$.

toward higher wavelengths. For the TaON and TON/Ag sputtered samples, the spectral intensity increases with sputtering time. For samples containing $\mathrm{Ag}$ in Fig. $4 \mathrm{~b}$, the intense spectral absorption between 400 and $600 \mathrm{~nm}$ is due to the localized surface resonance of the Ag-plasmons. These plasmons interacting with TaON preclude the red tail in the TaON spectra shown in Fig. 4a.

\subsection{Evaluation of the Ag and Ta-contents in the TaN/Ag and TaON/Ag films}

The Ag and Ta-content of the sputtered samples were determined by X-ray fluorescence (XRF) as shown in Table 1 for TaN/Ag and $\mathrm{TaON} / \mathrm{Ag}$ samples. The most effective photocatalyst (TaON/Ag) co-sputtered for $120 \mathrm{~s}$ had a Ta-content of $0.09 \mathrm{wt} \% \mathrm{Ta} / \mathrm{wt}$ polyester and an $\mathrm{Ag}$-content of $0.6 \mathrm{wt} \% \mathrm{Ag} / \mathrm{wt}$ polyester. $\mathrm{Ag}$ sputtered alone on polyester inactivated bacteria within longer times as shown in Fig. 2d.

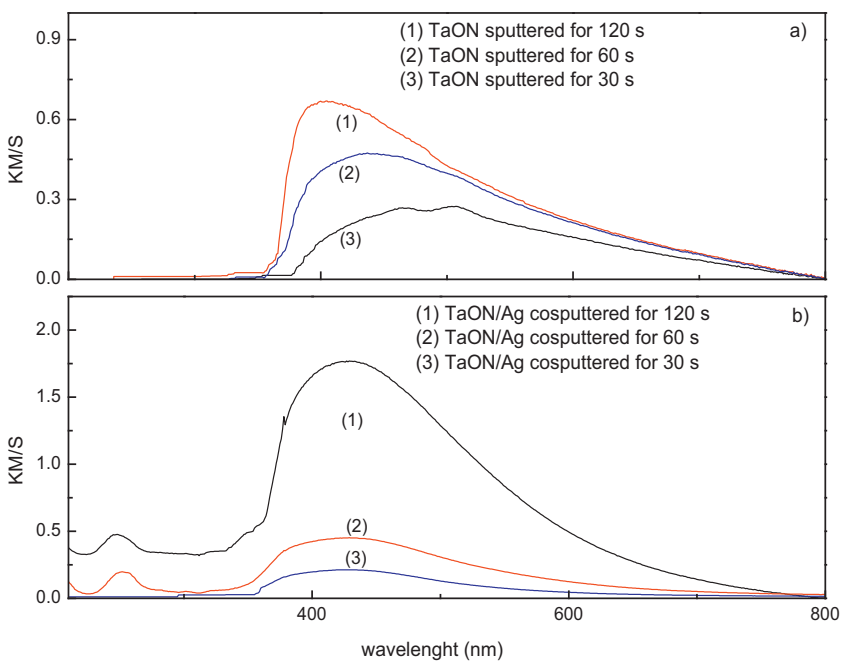

Fig. 4. Diffuse reflectance spectra in Kubelka-Munk units (a) sputtered TaON and (b) co-sputtered $\mathrm{TaON} / \mathrm{Ag}$ on polyester.
Table 1

$\mathrm{Ag}$ - and Ta-contents as a function of sputtering times on polyester.

\begin{tabular}{lcll}
\hline Samples & $\begin{array}{l}\text { Sputtering } \\
\text { time }(\mathrm{s})\end{array}$ & $\begin{array}{l}\% \mathrm{Ag}_{2} \mathrm{O} \mathrm{wt} / \mathrm{wt} \\
\text { polyester }\end{array}$ & $\begin{array}{l}\% \mathrm{Ta}_{2} \mathrm{O}_{5} \mathrm{wt} / \mathrm{wt} \\
\text { polyester }\end{array}$ \\
\hline TaN-Ag & 40 & 0.0089 & 0.0027 \\
& 60 & 0.0150 & 0.0078 \\
& 120 & 0.0288 & 0.0131 \\
$\mathrm{TaON} / \mathrm{Ag}$ & 40 & 0.0250 & 0.0147 \\
& 60 & 0.0471 & 0.0227 \\
& 120 & 0.0605 & 0.0929 \\
& 150 & 0.0941 & 0.1089 \\
\hline
\end{tabular}

\subsection{AFM and contact angle (CA) of TaON and TaON/Ag samples}

Fig. 5a shows the atomic force microscopy (AFM) for a sputtered TaON (120s) sample showing a non-uniform TaON grains with sizes of $40-60 \mathrm{~nm}$. Fig. 5b shows the AFM image for a cosputtered TaON/Ag (120 s) sample with grain sizes of $70-100 \mathrm{~nm}$. The root mean square (rms) roughness for the samples TaON and TaON/Ag were respectively 2.2 and $2.7 \mathrm{~nm}$. An increase in roughness leads to higher contact angle reducing the polarity and the total surface energy [23]. Increased sample rugosity allows for a better adhesion of the Ag-ions responsible for the bacterial inactivation (see Section 3.6).

The contact angles (CA) with $\mathrm{TaON}$ and $\mathrm{TaON} / \mathrm{Ag}$ polyester as a function of time after the bacterial inactivations are shown in Fig. 6a and ba and $\mathrm{b}$. The TaON sample after $2 \mathrm{~s}$ shows a CA of $80^{\circ}$ and after $6 \mathrm{~s}$ of $12^{\circ}$. The water droplet disappeared after $10 \mathrm{~s}$. This means that the TaON-polyester surface becomes completely hydrophilic after $10 \mathrm{~s}$ and eliminates any hydrophobic residues left by bacterial inactivation.
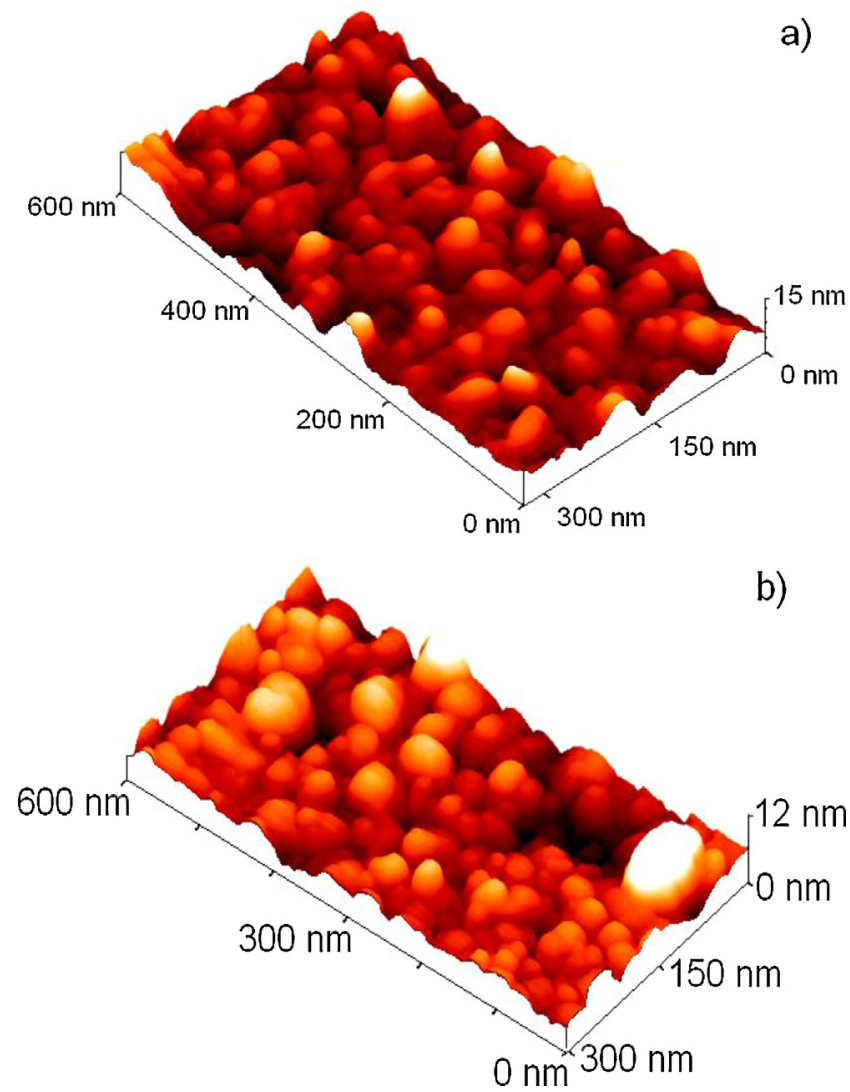

Fig. 5. Atomic force microscopy for polyester samples: (a) sputtered with TaON for $120 \mathrm{~s}$ time and (b) co-sputtered TaON/Ag for $120 \mathrm{~s}$. 
a)

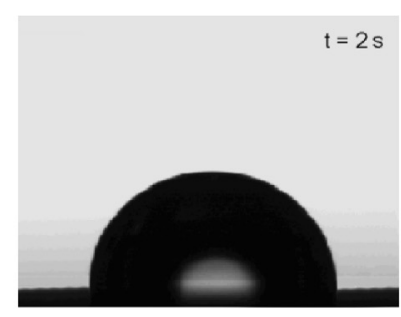

$80^{\circ}$

b)

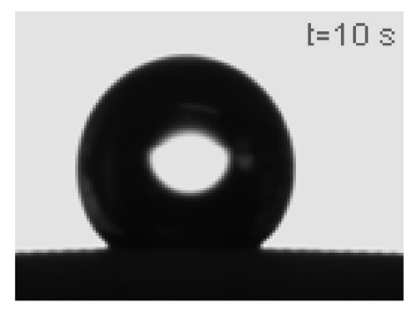

$108^{\circ}$

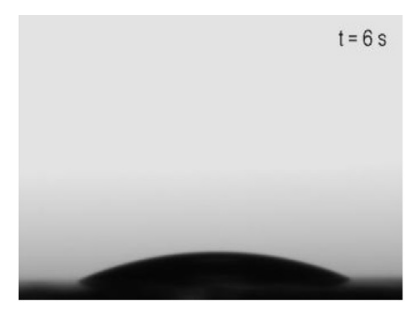

$12^{\circ}$

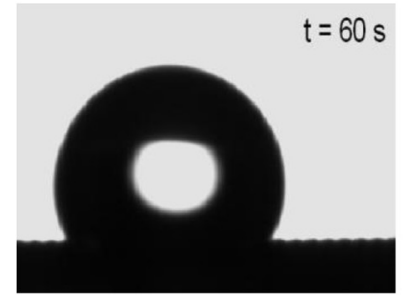

$94^{\circ}$

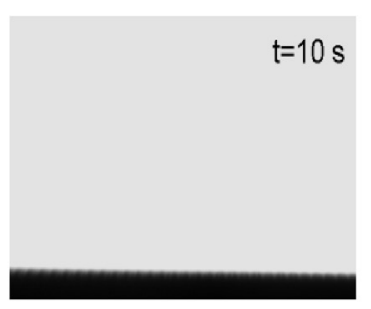

$0^{\circ}$

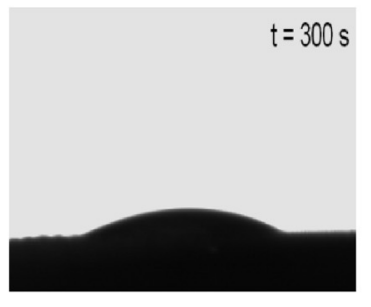

$14^{\circ}$

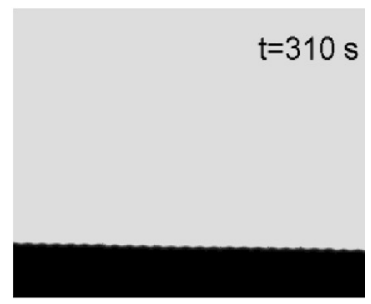

$0^{\circ}$

Fig. 6. Contact angle water-droplets as a function of contact time for: (a) TaON sputtered on polyester for $120 \mathrm{~s}$ and (b) TaON/Ag co-sputtered on polyester for $120 \mathrm{~s}$.

A water droplet on the polyester alone was observed to disappear by contact with the fabric. Although the polyester is hydrophobic, the polyester has a high amount of void areas/porosity promoting water penetration through the polyester microstructure. The sputtering TaON decreases the void areas leading to water penetration and concomitantly increasing the sample hydrophobicity. The amount of $\mathrm{O}_{2}$ plays a role in the contact angle of the surface. Studies on nitrides/oxynitrides have reported that $\mathrm{O}_{2}$ photo-adsorption introduces highly polar and electronegative groups compared to $\mathrm{N}_{2}$ changing the electro-negativity and electron density of nitrides [12].

Fig. $6 \mathrm{~b}$ shows the CA of the water droplet on the surface of cosputtered $\mathrm{TaON} / \mathrm{Ag}$ polyester samples. A slower decrease of the CA with time was observed on the TaON sample in Fig. 6a. The CA varied from an initial value of $108^{\circ}$ at $10 \mathrm{~s}$ to $14^{\circ}$ within $300 \mathrm{~s}$ and disappears completely after $310 \mathrm{~s}$. The surface energy of $\mathrm{Ta}_{2} \mathrm{O}_{5}$ controls the surface CA [24]. The addition of Ag increases the hydrophobicity in the $\mathrm{TaON} / \mathrm{Ag}$ film surface leading to longer absorption times for the water droplet as shown in Fig. $6 \mathrm{~b}$.

\subsection{X-ray photoelectron spectroscopy (XPS) and spectral deconvolution}

The XPS spectrum of the TaON sample is shown in Fig. 7a. The TaON spectral deconvolution of shows a peak at $24.2 \mathrm{eV}$ for TaON and another peak for $\mathrm{Ta}_{2} \mathrm{O}_{5}$ at $25.9 \mathrm{eV}$, and was carried out by means of the CasaXPS-Vision 2 software. Recently, Chun et al. [23] demonstrated that TaON and $\mathrm{Ta}_{2} \mathrm{O}_{5}$ are stable species able to carry oxidation/reduction reactions under visible light.

Fig. 7b shows the $\mathrm{Ag} 3 \mathrm{~d} 5 / 2$ doublet with a split of $6 \mathrm{eV}$ found in the co-sputtered TaON/Ag films for $40 \mathrm{~s}, 60 \mathrm{~s}$ and $120 \mathrm{~s}$. Values for the Ag Auger parameter in Table 2 present the oxidation state of

Table 2

Surface atomic concentration percentage of elements during $E$. coli inactivation on TaON-Ag polyester (120 s) co-sputtered sample under light.

\begin{tabular}{llrlll}
\hline & O1s & Ta4f & N1s & Ag3d & C1s \\
\hline$t=0$ & 22.13 & 12.04 & 4.47 & 21.50 & 23.71 \\
$t=0$ contacted bacteria & 31.24 & 9.67 & 2.74 & 14.08 & 42.28 \\
$t=20$ min & 24.09 & 10.51 & 3.02 & 20.11 & 34.22 \\
$t=40$ min & 19.55 & 12.21 & 4.48 & 20.79 & 28.76 \\
\hline
\end{tabular}

silver. The shift in $\mathrm{BE}$ from $364.4 \mathrm{eV}$ to $364.9 \mathrm{eV}$ was due to the shift of the peaks of $\mathrm{AgO}$ to $\mathrm{Ag}_{2} \mathrm{O}$ and $\mathrm{Ag}^{0}$ as a function of sputtering times of $40 \mathrm{~s}, 60 \mathrm{~s}$ and $120 \mathrm{~s}$ respectively [18]. For the initial sputtering of $40 \mathrm{~s}$, the Auger parameter was found at $725.15 \mathrm{eV}$ and the $\mathrm{Ag}^{0}$
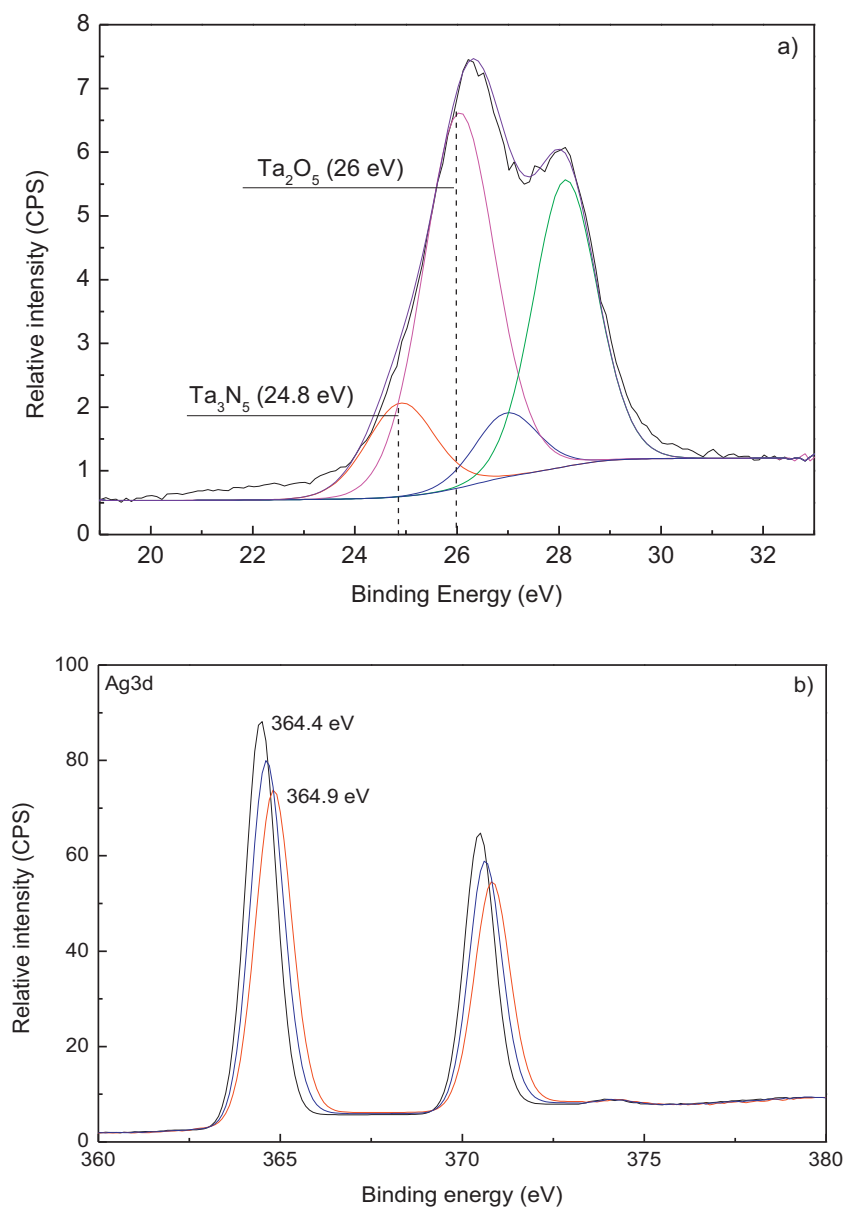

Fig. 7. (a) XPS spectra of Ta4f in TaON sputtered films and (b) Ag deconvolution in the co-sputtered TaON/Ag at $40 \mathrm{~s}, 60 \mathrm{~s}$ and $120 \mathrm{~s}$ films. 


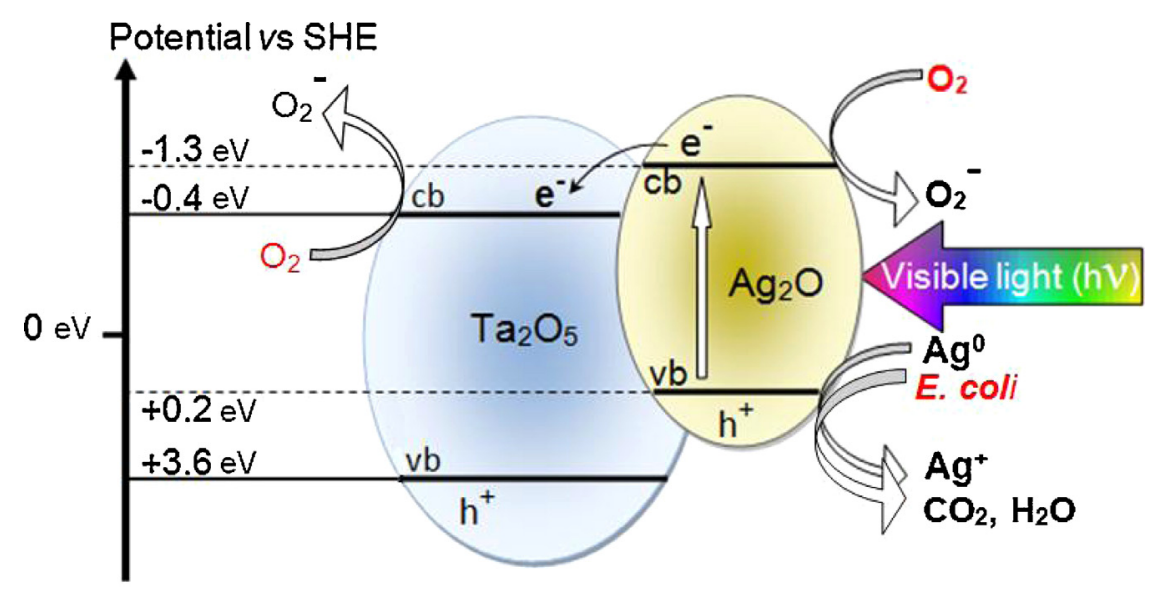

Fig. 8. Scheme for the photoinduced interfacial charge transfer (IFCT) from $\mathrm{Ag}_{2} \mathrm{O}$ to $\mathrm{Ta}_{2} \mathrm{O}_{5}$ under visible light irradiation.

content of the TaON sample is very low. At longer deposition times, the Auger parameter at $725.65 \mathrm{eV}$ suggests the formation of $\mathrm{Ag}^{0}$ along a low amount of ionic silver. To separate the ionic states of $\mathrm{Ag}$ is not a simple matter due to the electrostatic charging of the sample but shifts of $0.2 \mathrm{eV}$ or more are generally accepted as evidence for the change in the electronic configuration of a species detected by XPS [24]. Values for the Ag Auger parameter in Table 3 present the oxidation state of silver.

The TaON/Ag surface binds the protein $\mathrm{N}$-amides I/II, carboxylic and S-groups of the bacterial cell wall containing negative surface charged functional groups [3,4]. The Ag-ions react with the bacterial cell-wall leadings to cell damage and bacterial inactivation as reported in Fig. 2a-e.

\subsection{Suggested mechanism for the photo-induced IFCT process}

The photo-induced interfacial charge transfer from the Aglayers to the TaON layers will be discussed in this section. Visible light is absorbed by the narrow band semiconductor $\mathrm{Ag}_{2} \mathrm{O}$ up to $880 \mathrm{~nm}$ and the wide band semiconductor $\mathrm{Ta}_{2} \mathrm{O}_{5}$ absorbs UVlight $<310 \mathrm{~nm}$. In Fig. 8, a mechanism for electron injection for the charge transfer from $\mathrm{Ag}_{2} \mathrm{O}$ into $\mathrm{Ta}_{2} \mathrm{O}_{5}$ is suggested. This mechanism considers the potential energy of the semiconductor bands [23]. When the sputtered Ag layer is exposed to air, the water vapor in the air leads to the formation of surface $\mathrm{AgOH}$. The $\mathrm{AgOH}$ has been reported to decompose spontaneously to $\mathrm{Ag}_{2} \mathrm{O}$ (Eq. (1)) [24].

$2 \mathrm{AgOH} \rightarrow \mathrm{Ag}_{2} \mathrm{O}+\mathrm{H}_{2} \mathrm{O}(p k=2.87)$

$\mathrm{Ag}_{2} \mathrm{O}$ is thermodynamically stable at $\mathrm{pH} 6-7$. This is the $\mathrm{pH}$ range at which the bacterial inactivation proceeds in Fig. $2 \mathrm{a}-\mathrm{d}$. The $\mathrm{Ag}_{2} \mathrm{O}$ has been reported with a cb at $-1.3 \mathrm{eV} \mathrm{NHE}(\mathrm{pH} 0)$, vb at $+0.2 \mathrm{~V} \mathrm{NHE}$ $(\mathrm{pH} 0)$ and bg of $1.5 \mathrm{eV}$. The wide band-gap semiconductor $\mathrm{Ta}_{2} \mathrm{O}_{5}$ has been reported with a cb at $-0.4 \mathrm{~V}, \mathrm{vb}$ at $+3.6 \mathrm{~V} \mathrm{NHE}(\mathrm{pH} 0)$ and a bg of $4.0 \mathrm{eV}$ [23].

The electron injection from $\mathrm{Ag}_{2} \mathrm{O}$ to the $\mathrm{Ta}_{2} \mathrm{O}_{5}$ is thermodynamically favorable. The $\mathrm{Ag}_{2} \mathrm{O}(\mathrm{cb})$ at $-1.3 \mathrm{eV}$ NHE lays above the $\mathrm{Ta}_{2} \mathrm{O}_{5} \mathrm{cb}$ at $0.4 \mathrm{eV}$ NHE. The potential $1.7 \mathrm{eV}$ difference in provides a considerable driving force inducing a fast electron injection from $\mathrm{Ag}_{2} \mathrm{O}$ into $\mathrm{Ta}_{2} \mathrm{O}_{5}$. Due to the magnitude of this driving potential the $\mathrm{Ag}_{2} \mathrm{O}$ transfers the majority of the electrons to the $\mathrm{Ta}_{2} \mathrm{O}_{5} \mathrm{Cb}$ hindering the $\mathrm{e}^{-} / \mathrm{h}^{+}$recombination in $\mathrm{Ag}_{2} \mathrm{O}$. The values for the potentials for the $\mathrm{cb}$ for both semiconductors are only indicative, since in quantum size nanoparticles, the band energy shifts have been reported to higher potentials $[25,26]$. The reductive character in the quantum size $\mathrm{Ag}_{2} \mathrm{O}$ particles proceeds at a higher energy level than $-1.3 \mathrm{eV}$ NHE. The potential energy of the $\mathrm{h}^{+}$at the $\mathrm{vb}$ of $\mathrm{Ta}_{2} \mathrm{O}_{5}(3.6 \mathrm{eV})$ becomes more positive than the standard reduction potential of $\mathrm{HO}^{\bullet} / \mathrm{HO}^{-}$of $\sim 1.9 \mathrm{eV}$ [3]. The $\mathrm{vb}$ holes $\mathrm{h}^{+}$will oxidize the $\mathrm{Ta}_{2} \mathrm{O}_{5}$ surface- $\mathrm{OH}$ to $\mathrm{OH}^{\bullet}$ and this radical subsequently oxidizes E. coli (see Fig. 8) [3,4]. The IFCT charge transfer would be favored by the close contact between $\mathrm{Ag}$ and Ta-particles sample in the co-sputtered TaON/Ag (120s) sample (see in Fig. 9). The higher activity of the coupled semiconductors may be also due to a higher density of defects in their crystallites.

Under visible light irradiation $\mathrm{Ag}_{2} \mathrm{O}$ gives raise to the charge separation

$\mathrm{Ag}_{2} \mathrm{O}+$ visiblelight $\rightarrow \mathrm{h}^{+}+\mathrm{e}^{-}$

$\mathrm{Ag}_{2} \mathrm{O}+\mathrm{e}^{-} \rightarrow 2 \mathrm{Ag}^{0}+\mathrm{O}^{-}$

$\mathrm{Ag}_{2} \mathrm{O}+\mathrm{e}^{-} \rightarrow 2 \mathrm{Ag}^{0}+1 / 2 \mathrm{O}_{2}$

The electron injection from the $\mathrm{Ag}_{2} \mathrm{Ocb}$ to the $\mathrm{Ta}_{2} \mathrm{O}_{5}(\mathrm{cb})$ hinders the charge recombination in $\mathrm{Ag}_{2} \mathrm{O}$ upon visible light excitation in Eq. (2). Concomitantly, the cbe- become available to reduce oxygen in Eq. (3a). The photo-induced electron Eq. (3b) lead to silver atoms and additionally produce highly oxidative radicals Eqs. (5) and (6). The (vb)h $\mathrm{h}^{+}$Eq. (2) reacts with $\mathrm{H}_{2} \mathrm{O}$ in Eq. (4) leading to $\mathrm{OH}^{\bullet}$ radicals or other highly oxidative oxidative radicals in Eq. (5)

$\mathrm{h}^{+}+\mathrm{H}_{2} \mathrm{O} \rightarrow \mathrm{OH}^{\bullet}+\mathrm{H}^{+}$

$\mathrm{e}^{-}+\mathrm{H}_{2} \mathrm{O}+1 / 2 \mathrm{O}_{2} \rightarrow \mathrm{OH}^{\bullet}+\mathrm{OH}^{-}$

$\mathrm{e}^{-}+\mathrm{O}_{2} \rightarrow \mathrm{O}_{2}^{-}$

Within the band-gap of each semiconductor there are intermediate electron transitions between the $\mathrm{cb}$ and the vb band. More information is needed about these indirect transitions at the present time. Studies have reported visible light induced electron injection from $\mathrm{Ag}$ into $\mathrm{TiO}_{2}$ leading to surface $\mathrm{Ag}^{0} / \mathrm{Ag}_{2} \mathrm{O}$.

\subsection{Electron microscopy of polyester modified samples (TEM)}

Fig. 9 presents the TEM of (a) the polyester sample and (b) the TEM of a TaON/Ag co-sputtered sample showing the $\mathrm{Ta}_{2} \mathrm{O}_{5}$ clearer particles presenting sizes $5-8 \mathrm{~nm}$. The $\mathrm{Ag}$-particles were found to be $10-16 \mathrm{~nm}$ (counting for 100 particles) with an interfacial particle distance up to $10 \mathrm{~nm}$ between $\mathrm{Ta}_{2} \mathrm{O}_{5}$ and $\mathrm{Ag}_{2} \mathrm{O}$. The close contact in the co-sputtered $\mathrm{TaON} / \mathrm{Ag}$ sample compared to the samples sputtering sequentially $\mathrm{TaON}$ and $\mathrm{Ag}$, a closer contact between both occurs inducing higher quantum efficiency. This led to shorter bacterial inactivation times for the co-sputtered samples compared to the sequentially sputtered sample. 

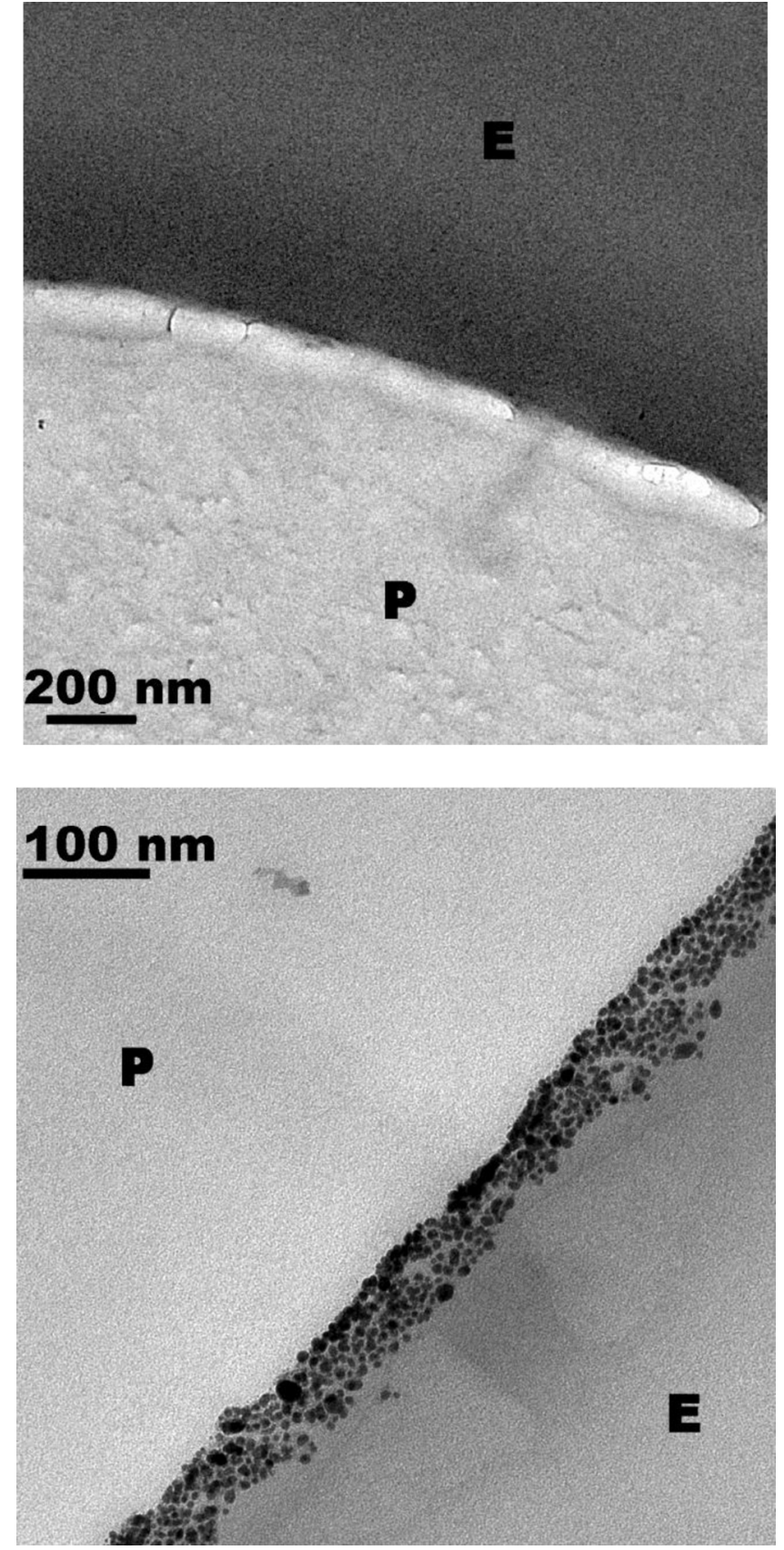

Fig. 9. Electronic microscopy of: (a) polyester fiber and (b) sputtered TaON/Ag (120 s) film on polyester (E: epoxy, P: polyester).

Small particles of less than $10 \mathrm{~nm}$ as shown in Fig. 9 show different properties from those in bulk materials. The quantum size effect is applicable to particles with sizes $10 \mathrm{~nm}$ having about $10^{4}$ atoms [3]. The quantum size nature of the semiconductors particles has been reported to introduce a marked perturbation in their band structure $[3,12,26]$.

Donor-acceptor interactions depend on the charge diffusion distance and this distance is a function of the particle size and shape. But unfavorable effects associated with small size are also known and cannot be discounted in our samples. First, the recombination time for the induced charges on $\mathrm{Ag}_{2} \mathrm{O}$ becomes shorter due to the decrease of the available space for the charge separation and second, the decrease of the space charge layer with the consequent decrease in potential depth. Nevertheless, the co-sputtered samples lead to fast inactivation kinetics (Fig. 2b)

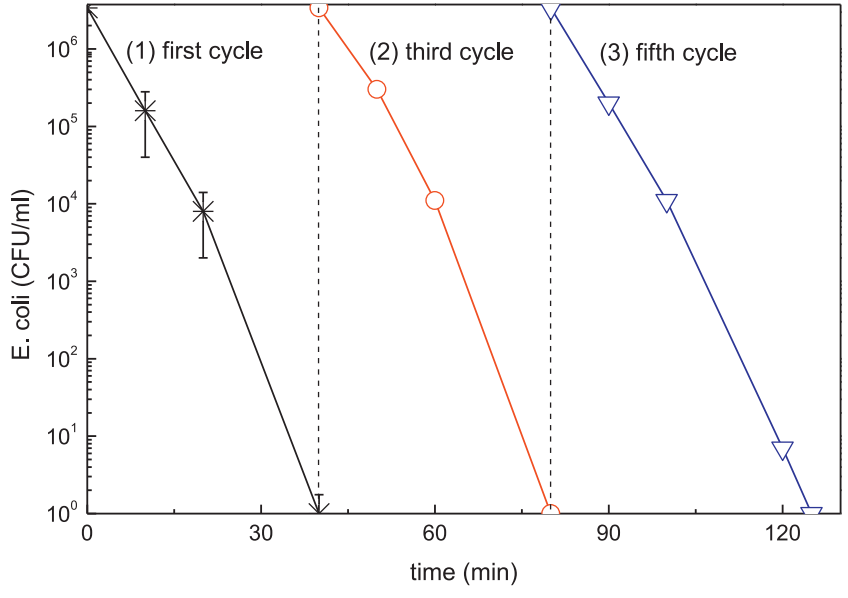

Fig. 10. Recycling of $\mathrm{TaON} / \mathrm{Ag}(120 \mathrm{~s})$ during E. coli bacterial inactivation for 5 cycles: (1) first cycle; (2) third cycle and (3) fifth cycle.

Table 3

Auger parameters of $\mathrm{Ag}$ in co-sputtered TaON/Ag samples.

\begin{tabular}{lll}
\hline $\begin{array}{l}\text { Sputtering } \\
\text { time }(\mathrm{s})\end{array}$ & $\begin{array}{l}\text { Auger parameters } \\
\text { of } \mathrm{Ag}(\mathrm{eV})[13,21]\end{array}$ & $\begin{array}{l}\text { Auger parameters of Ag in the } \\
\text { co-sputtered TaON/Ag samples }(\mathrm{eV})\end{array}$ \\
\hline 40 & 725.15 & 725.15 \\
60 & 725.15 & 725.53 \\
120 & 725.52 & 725.65 \\
150 & 725.65 & 725.66 \\
\hline
\end{tabular}

presenting a microstructure able to: (a) preclude to some extent electron-hole recombination [22], (b) further the interfacial transfer (IFCT) between $\mathrm{Ag}_{2} \mathrm{O}$ and $\mathrm{Ta}_{2} \mathrm{O}_{5}$ and (c) improve the charge transfer between the film and the bacterial surface $[12,13,22,26]$.

\subsection{Recycling of the sputtered polyester samples}

The recycling of the co-sputtered TaON/Ag (120 s) sample up to the 5th cycle is seen in Fig. 10. It proceeds with no significant loss in activity since the bacterial inactivation time remained the same. The sample was thoroughly washed after each recycling experiment. The reuse of the co-sputtered TaON/Ag samples is possible since total bacterial destruction was attained at each cycle. The total destruction of the bacterial residues enables a stable sample recycling due to the $\mathrm{TaON} / \mathrm{Ag}$-samples self-clean as shown in Table 2. The $\mathrm{N}$ - and $\mathrm{C}$-bacterial residues did not accumulate on the polyester due to the rapid catalytic destruction of these elements on the photocatalyst surface. A slow increase in the C-content with time is shown in Table 2 within the time of bacterial inactivation. This is due to adventitious hydrocarbons spontaneously adsorbed from the air on the film surface, while $\mathrm{O}, \mathrm{Ta}, \mathrm{N}, \mathrm{Ag}$ percentage surface concentration remains stable. A further proof of the surface self-cleaning is provided by the contact angle shown in Fig. $6 \mathrm{~b}$. The fact that the CA vanishes after $310 \mathrm{~s}$ indicates that no hydrophobic compounds remain on the sample surface after the bacterial inactivation (Table 2).

\section{Conclusions}

TaON and TaON/Ag films on polyester are shown to be able to inactivate bacteria in the minute range under low intensity visible/actinic light $(340-700 \mathrm{~nm})$ light. The fastest inactivation kinetics within $40 \mathrm{~min}$ was obtained with $\mathrm{TaON} / \mathrm{Ag}$-polyester cosputtered samples for $120 \mathrm{~s}$. By XPS spectral deconvolution $\mathrm{Ta}_{2} \mathrm{O}_{5}$ and $\mathrm{Ag}_{2} \mathrm{O}$ were identified in the $\mathrm{TaON} / \mathrm{Ag}$ photocatalyst. Evidence is presented for the interfacial charge transfer mechanism (IFCT) between $\mathrm{Ag}_{2} \mathrm{O}$ and $\mathrm{Ta}_{2} \mathrm{O}_{5}$. The $\mathrm{Ag}$-species is the visible light 
absorber and transfers the photo-induced charges to $\mathrm{Ta}_{2} \mathrm{O}_{5}$. AFM and TEM of the sputtered films show a uniform coating of TaON/Ag layers on polyester. Contact angle (CA) and X-ray fluorescence were also carried out to characterize the surface of the TaON and $\mathrm{TaON} / \mathrm{Ag}$ layers.

\section{Acknowledgments}

We thank, the EPFL and LIMPID FEP-7 Collaborative European Project Nanocomposite Materials NMP 2012.2.2.2-6 (N. 310177) for financial support of this work and COST Actions MP0804, MP1106 and TD0906 for interactive discussions during the course of this study.

\section{References}

[1] Thüringer Surface and Biomaterials Kolloquium, 13/15 September 2012, Zeulenroda, Germany.

[2] A. Kramer, I. Schwebke, G. Kampf, How long do socomial pathogens persist in on inanimate surfaces? BMC Infect. Dis. 130 (2006) 137-146.

[3] A. Mills, C. Hill, P. Robertson, Overview of the current ISO tests for photocatalytic materials, J. Photochem. Photobiol. A 237 (2012) 7-23.

[4] K. Page, M. Wilson, P.I. Parkin, Antimicrobial surfaces and their potential in reducing the role of the inanimate environment in the incidence of hospitalacquired infections, J. Mater. Chem. 19 (2009) 3819-3831.

[5] S. Noimark, Ch. Dunnill, M. Wilson, P.I. Parkin, The role of surfaces in catheterassociated infections, Chem. Soc. Rev. 38 (2009) 3435-3448.

[6] P.I. Parkin, G.R. Palgrave, Self-cleaning coatings, J. Mater. Chem. 15 (2005) $1689-1695$

[7] K. Page, R. Palgrave, P.I. Parkin, M. Wilson, Sh. Savin, A. Chadwick, Titania and siver titania composite films on glass-potent antimicrobial coatings, J. Mater. Chem. 17 (2007) 95-104.

[8] H.A. Foster, P. Sheel, W.D. Sheel, P. Evans, S. Varghese, N. Rutschke, M.H. Yates, Antimicrobial activity of titania/silver and titania/copper films prepared by CVD, J. Photochem. Photobiol. A 216 (2010) 283-289.

[9] M.S.P. Dunlop, P.C. Sheeran, A.J. Byrne, S.A. McMahon, M.A. Boyle, G.K. McGuigan, Inactivation of clinically relevant pathogens by photocatalytic coatings, J. Photochem. Photobiol. A 216 (2010) 303-3010.

[10] M.H. Yates, A.L. Brook, B.I. Ditta, P. Evans, H.A. Foster, D.W. Sheel, A. Steele, Photo-induced self-cleaning and biocidal behviour of titania and copper oxide multilayers, J. Photochem. Photobiol. A 197 (2008) 197-208.
[11] R. Asahi, T. Morikawa, T. Ohwaki, K. Aoki, Y. Taga, Visible-light photocatalysis in nitrogen-doped titanium oxides, Science 293 (2001) 269-273.

[12] M. Mohamed, D. Bahneman, The role of electron transfer in photocatalysis: fact and fictions, Appl. Catal. B 128 (2012) 91-104.

[13] S. Rtimi, O. Baghriche, R. Sanjines, C. Pulgarin, M. Ben-Simon, J-C. Lavanchy, A. Houas, J. Kiwi, Photocatalysis/catalysis by innovative TiN and TiN-Ag surfaces inactivate bacteria under visible light, Appl. Catal. B 123-124 (2012) 306-313.

[14] S. Rtimi, O. Baghriche, O. Pulgarin, R. Sanjines, J. Kiwi, Design, testing and characterization of innovative TiN-TiO 2 surfaces inactivating bacteria under low intensity visible light, RSC Adv. 2 (2012) 8591-8595.

[15] P. Kelly, H. Li, P. Benson, K. Whitehead, J. Verran, R. Arnell, I. Iordanova, Comparison of the tribological and antimicrobial properties of $\mathrm{CrN} / \mathrm{Ag}, \mathrm{ZrN} / \mathrm{Ag}$, TiN/Ag and TiN/Cu nanocomposite coatings, Surf. Coat. Technol. 205 (2010) 1606-1610.

[16] P. Kelly, H. Li, K. Whitehead, J. Verran, R. Arnell, I. Iodornova, A study of the antimicrobial and tribological properties of TiN/Ag nanocomposite coatings, Surf. Coat. Technol. 204 (2009) 1137-1141.

[17] L. Geranio, M. Heuberger, E. Nowack, The behavior of silver nano textiles during washing, Environ. Sci. Technol. 43 (2009) 8113-8118.

[18] D. Wagner, M. Riggs, E. Davis, G. Müllenberg (Eds.), Handbook of X-ray Photoelectron Spectroscopy, Perkin-Elmer Corporation, Physical Electronics Division, Minnesota, 1979.

[19] D.A. Shirley, High-resolution X-ray photoemission spectrum of the valence bands of gold, Phys. Rev. B 5 (1972) 4709-4716.

[20] J. Mathews, Epitaxial Growth Part B, IBM Thomas Watson Research Center Academic Press, New York, 1975, pp. 382-436.

[21] O. Baghriche, R. Sanjines, C. Ruales, C. Pulgarin, I. Stolitchnov, A. Zertal, J. Kiwi, $\mathrm{Ag}$-surfaces sputtered by DC and pulsed DC-magnetron sputtering effective in bacterial inactivation: testing and characterization, Surf. Coat. Technol. 206 (2011) 2410-2416

[22] C. Creutz, S. Bruce, S. Brunschwig, S. Sutin, Interfacial charge transfer absorption: application to metal-molecule assemblies, Chem. Phys. 324 (2006) $244-258$.

[23] W. Chun, A. Ishikawa, H. Fujisawa, T. Takata, N. Kondo, M. Hara, M. Kawai, Y. Matsumoto, K. Domen, Conduction and valence band positions of $\mathrm{Ta}_{2} \mathrm{O}_{5}, \mathrm{TaON}$ and $\mathrm{Ta}_{3} \mathrm{~N}_{5}$ by UPS and electrochemical methods, J. Phys. Chem. B 107 (2003) 1798-1803.

[24] G. Biedermann, G. Sillen, Studies on the hydrolysis of metal ions. Part 30. A critical survey of the solubility equilibria of $\mathrm{Ag}_{2} \mathrm{O}$, Acta Chem. Scand. 14 (1960) $07-17$.

[25] Y. Ida, T. Watase, M. Shinagawa, M. Watabanbe, M. Chigane, M. Inaba, A. Tasaka, M. Izaki, Direct electrodeposition of $1.46 \mathrm{eV}$ bandgap silver(I) oxide semiconductor films by electrogenerated acid, Chem. Mater. 20 (2008) 1254-1256.

[26] A. Nozik, Photoeffects at the semiconductor electrolyte interface, in: ACS Symp. Ser. 140, Amer. Chem. Soc., Washington, 1990. 